\title{
Characterization of the efficiency of soybean inoculation
}

\author{
O. GAZDAG, L. KÖDÖBÖCZ, T. SzILI-KovÁCS and A. MuRÁNYI \\ Institute for Soil Sciences and Agricultural Chemistry, Centre for Agricultural \\ Research, Hungarian Academy of Sciences, Budapest (Hungary)
}

\section{Introduction}

With its high protein content and high concentration of amino acids, soybean is a key component of the food and animal feed chain. The demand for soybean in the EU far exceeds its 0.9 million tons per year production and imports reach around 30-35 million $t \cdot$ year $^{-1}$ (FAO, 2012), so its cultivation has important economic and political implications.

The total demand for soybean in Hungary is $900000 \mathrm{t} \cdot \mathrm{year}^{-1} .90-100000 \mathrm{t} \cdot \mathrm{year}^{-1}$ soybean is produced locally and approximately $800000 \mathrm{t} \cdot \mathrm{year}^{-1}$ is imported from South America. Soybean production in Hungary reached its lowest level in 1994, when the total sowing area was 9197 ha, with a yield of $16665 \mathrm{t} \cdot$ year $^{-1}$. From 1994 to 2011 the sowing area rose to $41458 \mathrm{ha}$, with a total yield of $94955 \mathrm{t} \cdot$ year $^{-1}$.

In the same period the average yields rose from $1.84 \mathrm{t} \cdot \mathrm{ha}^{-1}$ to $2.32 \mathrm{t} \cdot \mathrm{ha}^{-1}$ (HuNGARIAN CENTRAL STATISTICAL OFFICE, 2014). The potential sowing area for soybean in Hungary is approximately 300000 hectares.

The results of modern genetic analyses have proved that soybean can be infected by six rhizobia belonging to three different genera, namely Bradyrhizobium, Mesorhizobium and Sinorhizobium (VAN BERKUM \& EARDLY, 1998). The choice of microsymbiont species for soybean inoculation is greatly dependent on soil properties (SzEGI, 1967). While the efficiency of Sinorhizobium strains is higher in alkaline soils, Bradyrhizobium strains are more successful under neutral or slightly acidic pH conditions (ALBAREDA et al., 2009).

In order to achieve optimal soybean yields via rhizobial inoculation, various conditions need to be considered. The average yield of soybean is in the range of 0.58-5.89 $\mathrm{t} \cdot \mathrm{ha}^{-1}$, while its average nitrogen uptake is $219 \mathrm{~kg} \cdot \mathrm{ha}^{-1}$. The yield and total nitrogen uptake are directly proportional, so $1 \mathrm{~kg}$ nitrogen is needed for the development of $12.7 \mathrm{~kg}$ soybean yield (SALVAGIOTTI et al., 2008). Some 36-69\% of the total nitrogen utilised by soybean comes from biological nitrogen fixation (BNF). Even higher values were measured on subequatorial production areas, where the plants are able to use solar energy more efficiently (HUNGRIA et al., 2005). The efficiency of BNF may be influenced by various ecological soil factors,

Correspondence to: LÁSZLÓ KÖDÖBÖCZ, Department of Soil Biology and Soil Biochemistry, Institute for Soil Sciences and Agricultural Chemistry, CAR Hungarian Academy of Sciences, H-1022 Budapest, 15 Herman Ottó út. Hungary. E-mail: kodobocz@ hotmail.com 
such as the $\mathrm{pH}$, water content, nitrogen content, etc. So-called starter nitrogen doses may support BNF. A dose of 40-80 kg of nitrogen per hectare increases the symbiotic nitrogen fixation proportionally; however, larger nitrogen addition could reduce BNF (CALISKAN et al., 2008).

The yield response of soybean to $\mathrm{N}$ fertiliser application depends on the yield potential of the production environment and any abiotic or biotic constraints that reduce crop growth and associated $\mathrm{N}$ demand. When such constraints exist, the development of rhizobia strains able to fix nitrogen under stress conditions appears to be the most feasible way to secure the required $\mathrm{N}$ supply (SALVAGIOTTI et al., 2008). In an earlier study (KÖVES-PÉCHY et al., 1990), "Baktoleg" inoculant was used in a pot experiment with typical Hungarian soil types. It was found that the survival of soybean microsymbionts depended on the soil type, climatic conditions and the bacterial strains, so yearly bacterial inoculation is recommended to achieve efficient nodulation and nitrogen fixation in soybean. It was also demonstrated that for several of the soil types used, additional supplies of mineral fertilizers, i.e. P and $\mathrm{K}$, were able to improve the nodulation of five different leguminous crops, including soybean (BIRÓ et al., 1993; MATICS et al., 2014). At present there is a lack of information about the interaction between rhizobial inoculation and foliar fertilisation for soybean (KÖDÖBÖcZ et al., 2011).

The objectives of the present work were to study the efficiency of a composite peat-based inoculum under field conditions, to check the infectivity of introduced Bradyrhizobium strains isolated from the nodules of soybean in the field experiment and to reveal whether BNF could be supported by the enhanced photosynthesis promoted by foliar fertilisation. It was assumed that increased photosynthesis might support BNF and enhance the symbiotic efficiency of Bradyrhizobium strains.

\section{Materials and methods}

\section{Soil characteristics}

The test field was located near Mezőhegyes (Hungary), the soil type was loamic gleyic chernozem (WORLD REFERENCE BASE FOR SOIL RESOURCES, 2014). Soil samples were taken from the upper $20 \mathrm{~cm}$ layer, air-dried, ground and sieved through a $2 \mathrm{~mm}$ mesh for physical and chemical analysis.

Electrical conductivity (EC), $\mathrm{pH}(\mathrm{KCl})$, humus content, total $\mathrm{N}, \mathrm{NO}_{3}-\mathrm{N}, \mathrm{NH}_{4}-\mathrm{N}$ contents and plasticity index according to Arany were measured (KÖDÖBÖCZ et al., 2011).

Quality control of the Bradyrhizobium inoculum

The quality of the peat-based commercial soybean inoculum "Poliriz S" (KöDÖBÖCZ et al., 2011), consisting of six Bradyrhizobium japonicum strains, was checked before conducting the field experiment. The number of living cells and the purity of the inoculum were determined. 
A dilution series of up to $10^{7}$ fold was prepared from $1 \mathrm{~g}$ of the Poliriz inoculum and $100 \mu \mathrm{L}$ of each dilution was plated on yeast-extract mannitol agar medium (YMA), as suggested by VINCENT (1970). The plates were incubated at $28{ }^{\circ} \mathrm{C}$ for 5 days. Colonies were counted and the number of living cells per gram of product was calculated.

\section{BOX PCR assay}

Randomly selected colonies were isolated from the plates, and 16 single strains were grouped on the basis of their BOX-PCR profiles (LOUws et al., 1994). The polysaccharides that inhibit PCR were removed from the cells with $\mathrm{KCl}(0.85 \%)$. Before DNA extraction the cells were lysed by freezing. The DNA extracts were stored at $-20{ }^{\circ} \mathrm{C}$ until use. Total soil DNA concentration was quantified using a fibre-optic microlitre cell (Tray Cell, Hellma) with a Helios Beta spectrophotometer (Thermo Spectronic). The average total DNA yield was calculated from the absorbance at $260 \mathrm{~nm}(\mathrm{~A} 260)$.

BOX-PCR assay targeting the BOX repetitive element was performed using the BOXA1R primer (5'-CTACGGCAAGGCGACGCTGACG-3') (VERSALOVIC et al., 1994).

DNA amplification was performed in a total volume of $50 \mu \mathrm{l}$, containing $100 \mu \mathrm{M}$ of BOXA1 primer, $24 \mu 1$ Master Mix Dream Taq Green 2x and the DNA extract. PCR amplifications were performed in a thermal cycler (ICYCLER, BIO-RAD) with an initial denaturation $\left(95{ }^{\circ} \mathrm{C}, 2 \mathrm{~min}\right)$ followed by 35 cycles of denaturation $\left(92{ }^{\circ} \mathrm{C}\right.$, $\left.30 \mathrm{sec}\right)$, annealing $\left(50{ }^{\circ} \mathrm{C}, 1 \mathrm{~min}\right)$, and extension $\left(65^{\circ} \mathrm{C}, 8 \mathrm{~min}\right)$, with a single final extension $\left(65^{\circ} \mathrm{C}, 8 \mathrm{~min}\right)$.

Each PCR reaction was then electrophoresed directly on $1.5 \%$ agarose gels containing 1x TAE (Tris acetate-EDTA) buffer.

UVIband Advanced software was used for UPGMA (Unweighted Pair Group Method with Arithmetic Mean) cluster analysis.

Strains isolated from the inoculum and representative of various groups were identified on the basis of partial 16S rRNA gene sequence analysis.

\section{Inoculation and foliar fertilisation of soybean in a field experiment}

A field experiment was set up to test the symbiotic efficiency of Poliriz S inoculum on a chernozem soil near Mezőhegyes (Hungary). Soybean seeds (Glycine max (L.) Kurca) were inoculated 24 hours prior to sowing.

After dissolving $100 \mathrm{~g}$ of sucrose in $1 \mathrm{~L}$ water, $0.3 \mathrm{~kg}$ inoculum was added. A total of $5 \times 10^{11}$ colony-forming units (CFU) of inoculum were added to $80 \mathrm{~kg}$ per hectare soybean seeds and mixed. Three plots, all measuring one hectare were used: control without inoculation, inoculated with Poliriz S, and inoculated with Poliriz S plus foliar fertilizer at the V5 growth stage (KöDÖBÖCZ et al., 2011). In the latter treatment $0.5 \mathrm{~kg}$ foliar fertilizer was diluted in $500 \mathrm{~L}$ water per hectare before spraying. 
The experiment was evaluated at full bloom, at the peak of nodule activity. Plants, together with rhizosphere soil, were sampled every five metres.

After cutting the aboveground biomass the height and green weight were measured and the number of flowers was counted. The dry weight was determined after drying ground, homogenised plant samples. The total nitrogen content and total element content of the plants were determined. The nodules were then removed from the roots and counted. The infection activity and symbiotic efficiency were characterised by the number and colour of the nodules. The bacterial strains were isolated from the nodules on YMA plates (VINCENT, 1970).

\section{Testing of the symbiotic efficiency of field isolates in a pot experiment}

A pot experiment was carried out to test the symbiotic efficiency of the strains isolated from the test field. A total of 25 Bradyrhizobium strains were tested in three replicates.

Soybean seeds (Glicine max (L.) Kurca) were sown in pots containing $1000 \mathrm{~g}$ of air-dried sandy soil from Örbottyán, Hungary. The main properties of the soil were: electric conductivity (EC) $0.094 \mathrm{mS} \cdot \mathrm{cm}^{-1} ; \mathrm{pH}\left(\mathrm{H}_{2} \mathrm{O}\right)$ 5.90; $\mathrm{pH}(\mathrm{KCl})$ 4.77; humus content $0.55 \%$; total nitrogen $0.042 \% ; \mathrm{NH}_{4}-\mathrm{N} 24.0 \mathrm{mg} \cdot \mathrm{kg}^{-1} ; \mathrm{NO}_{3}-\mathrm{N} 0.87 \mathrm{mg} \cdot \mathrm{kg}^{-1}$ (MSZ-20135; BUZÁs, 1993). The air-dried soil was moistened with $300 \mathrm{~mL}$ water. The seedbed was inoculated with $5 \mathrm{~mL}$ of liquefied inoculum, containing $1 \times 10^{9}$ Bradyrhizobium cells.

The day/night period was $15 / 9 \mathrm{~h}$, with a light intensity of 25000 lux, while the temperature was $25 / 18{ }^{\circ} \mathrm{C}$, respectively.

The pot experiment was evaluated six weeks after sowing, at full bloom, when the shoot dry weight, plant height, total element content and nodule number were determined. The aboveground plant parts were dried, ground and homogenised.

In order to determine the total $\mathrm{N}$ content of the soybean, $5 \mathrm{~mL}$ of $\mathrm{H}_{2} \mathrm{SO}_{4}$ was added to $0.5 \mathrm{~g}$ of plant samples. The samples were placed in a block heater at a temperature of $150{ }^{\circ} \mathrm{C}$. After one hour the block temperature was raised to $350{ }^{\circ} \mathrm{C}$. The plant samples were digested for 5 hours. The nitrogen content was determined using the distillation method, in which $5 \mathrm{~mL}$ of $\mathrm{NaOH}\left(5 \mathrm{~mol} \cdot \mathrm{L}^{-1}\right)$ and phenolphthalein indicator were added to $20 \mathrm{~mL}$ of digested plant material. The distillation was carried out in a Gerhardt Vapodest 10 instrument. The distillate was titrated with $\mathrm{H}_{2} \mathrm{SO}_{4}\left(0.0025 \mathrm{~mol} \cdot \mathrm{L}^{-1}\right)$ in a Radiometer TitraLab 90 titration system.

Relationships between the nodule number per plant and the macroelement content were analysed with Statistica 9 software.

\section{Results}

\section{Soil properties}

There were no significant differences between the physical and chemical soil properties of the selected experimental fields (KÖDÖBÖCZ et al., 2011). 
According to these data the small differences in soil conditions could not have had a significant effect on yield or symbiotic efficiency. The soils had neutral $\mathrm{pH}(\mathrm{KCl})$ values. The $\left(\mathrm{K}_{\mathrm{A}}\right)$ plasticity index according to Arany indicated a clay loam soil.

Quality control of the inoculum

According to the product information, the number of living cells in Poliriz S, which contains six different strains, was at least $1.66 \times 10^{9} \mathrm{CFU} \cdot \mathrm{g}^{-1}$ inoculum. The quality of the inoculum was checked on yeast-extract mannitol agar (YMA) plates. No contaminating, infectious bacterial or fungal cultures could be detected on the YMA medium.

Sixteen bacterial isolates were randomly selected from the Poliriz $\mathrm{S}$ inoculum and grouped on the basis of their BOX-PCR pattern (Fig. 1). The dendrogram gave a homology coefficient $\%$ of 1.0 (UPGMA).

$10090 \% 80 \% \quad 70 \% \quad 60 \% \quad 50 \% \quad 40 \% \quad 30 \% \quad 20 \% \quad 10 \% 0 \%$

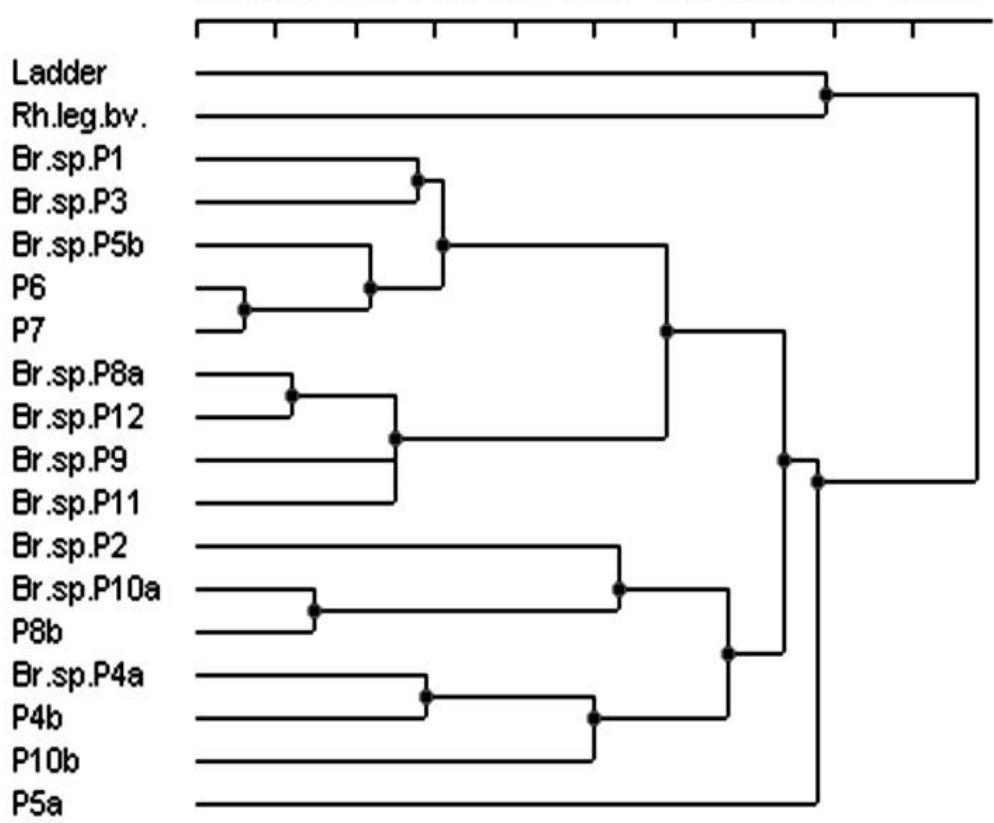

Fig. 1

Homology dendrogram (UPGMA) of Bradyrhizobium strains isolated from the Poliriz S inoculum. Legend: lane 1: GeneRuler, $1 \mathrm{~kb}$ plus; lane 2: positive control, Rhizobium leguminosarum; lanes 3-16: PCR products with BOXA1 primer; P1-P12: strains isolated from Poliriz S inoculum; Br. sp.: isolates identified as Bradyrhizobium species belonging to the Bradyrhizobiaceae family 
Table 1

NCBI BLAST results for strains P1-12, isolated from the Poliriz S inoculum

\begin{tabular}{|c|c|c|c|c|}
\hline Isolate & Hits & Accession \# & $\begin{array}{l}\text { Identity } \\
(\%)\end{array}$ & $\begin{array}{c}\text { Differences between } \\
\text { nucleotides }\end{array}$ \\
\hline \multirow{5}{*}{$\begin{array}{l}\text { P1, P2, } \\
\text { P3, P4a, } \\
\text { P5b, P8a, } \\
\text { P9, P10a, } \\
\text { P11, P12 }\end{array}$} & $\begin{array}{c}\text { Bradyrhizobium } \\
\text { yuanmingense }\end{array}$ & AB825991 & 100 & $0 / 379$ \\
\hline & $\begin{array}{c}\text { Bradyrhizobium } \\
\text { genosp. }\end{array}$ & JQ809910 & 100 & $0 / 379$ \\
\hline & $\begin{array}{c}\text { Bradyrhizobium } \\
\text { liaoningense }\end{array}$ & JQ659770 & 100 & $0 / 379$ \\
\hline & $\begin{array}{c}\text { Bradyrhizobium } \\
\text { japonicum }\end{array}$ & JQ514080 & 100 & 0/379 \\
\hline & Rhizobium lupini & AB649015 & 100 & $0 / 379$ \\
\hline
\end{tabular}

The BOX-PCR patterns were similar to each other in terms of soil bacterial diversity (Fig. 1). The isolates were $100 \%$ identical on the basis of partial 16S rRNA sequencing and were found to belong to the Bradyrhizobiaceae. family. BLAST analysis based on the NCBI (National Center for Biotechnology Information) and EzTaxon-e databases (KIM, 2012) also verified that the strains isolated from the Poliriz S inoculum belonged to the Bradyrhizobiaceae family (Table 1).

More accurate classification was not possible because the V1-V3 variable regions showed $>98 \%$ nucleotide identity with several species belonging to the $\mathrm{Bra}$ dyrhizobiaceae, so the profiles were grouped together. The inoculum quality was therefore suitable for the field experiment.

\section{Symbiotic efficiency of the inoculum strains}

The similarity of the inoculum strains and field isolates was compared on the basis of their BOX-PCR profiles (Fig. 2). The dendrogram showing the relationship between the BOX-PCR patterns had a homology coefficient \% of 1.0 (UPGMA). The community profiles were heterogeneous. Two similarity groups were determined. Inoculum strains P10B and P8B were the most effective. These were classified in the same similarity group as 18 field isolates. Strain P10B showed over 70\% similarity with nine field isolates, while the other strains isolated from the inoculum were only closely related to one or two field isolates.

\section{Soybean characteristics at full bloom}

Substantial differences were observed between the plants in terms of their colour and health. The plants in the control field were light green, turning to yellow, had thin stalks and showed typical nitrogen deficiency symptoms. The canopy failed to close even at full bloom. The plants in the inoculated field were dark green with thick stalks and a closed canopy. 


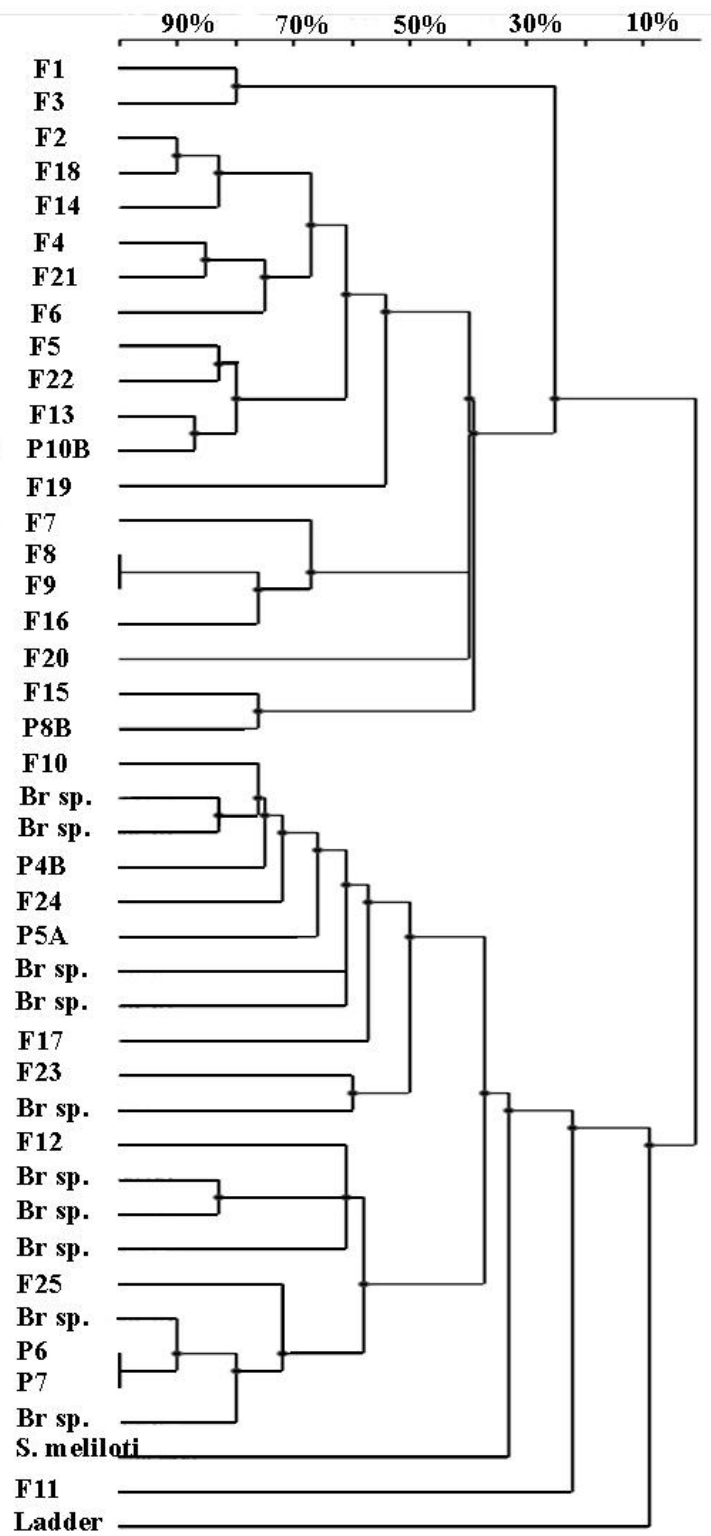

Fig. 2

BOX-PCR patterns and homology dendrogram (UPGMA) of Bradyrhizobium strains isolated from the Poliriz $\mathrm{S}$ inoculum and strains isolated from the root nodules of soybean plants in the field experiment (Legend: lanes 1-42: PCR products with BOXA1 primer; P1-P12: strains isolated from Poliriz S inoculum; Br. sp.: isolates identified as belong to the family of Bradyrhizobiaceae; S. meliloti. - Sinorhizobium meliloti; F1-F25: field isolates; lane 43: GeneRuler $1 \mathrm{~kb}$ plus) 
The height of the soybean plants increased significantly in response to inoculation. Foliar fertiliser application increased the height further, but this additional increment was not significant. The average dry weight of the aboveground biomass of the control field was $112 \mathrm{~g}$, while that of inoculated soybeans was $140 \mathrm{~g}$, i.e. $28 \mathrm{~g}$ higher than the control. Foliar fertiliser application did not lead to a further increase in biomass production.

The reproductive ability of soybean was characterised by the number of flowers which increased significantly due to inoculation. The control plants developed seven flowers or flower buds, while inoculated plants had an average of 11. Foliar fertiliser application did not increase the number of flowers.

The total shoot $\mathrm{N}$ content of inoculated plants was significantly higher than the control. Foliar fertiliser application had no effect on the total plant $\mathrm{N}$ content (KÖDÖBÖCZ et al., 2011).

\section{Characterisation of symbiotic efficiency}

The symbiotic efficiency was characterised in terms of nodulation (number and activity of nodules). No nodule formation was observed on the roots of soybean at in the non-inoculated control field in this experiment. However, numerous nodules were found on the roots of inoculated soybeans. Nodule formation was observed only on the main roots of the plants, indicating the efficiency of primary infection at the beginning of vegetative growth. The number of nodules ranged from 3 to 17 per plant, with an average of six nodules per plant. The application of foliar fertiliser treatment did not change the number of nodules significantly. All the nodules were pink or red, indicating the presence of leghemoglobin, and demonstrated active nitrogen fixation.

The soybean yields on control and inoculated fields were 1.22 and $2.46 \mathrm{t} \cdot \mathrm{ha}^{-1}$, respectively. The application of foliar fertiliser did not have a significant effect on the soybean yield.

\section{Pot experiment to verify the symbiotic efficiency of Bradyrhizobium strains}

Nodule formation was observed on all the inoculated soybean plants and the differences were significant. No nodule formation was observed on non-inoculated plants, which were chlorotic and stunted. Most of the nodules were located on the primary roots and were red or pink in colour. The average nodule number was 35 , with a standard deviation of 11 (Fig. 3). The $\mathrm{N}$ content of inoculated plants ranged from $1.9 \%$ to $3.07 \%$, the average being $2.58 \%$.

The average dry weight of inoculated plants was $116 \%$, the average height $119 \%$ and the average $\mathrm{N}$ content $107 \%$ compared to the control plants.

A significant correlation was found between the nodule number and $\mathrm{N} \%$ of soybean (Fig. 4). 


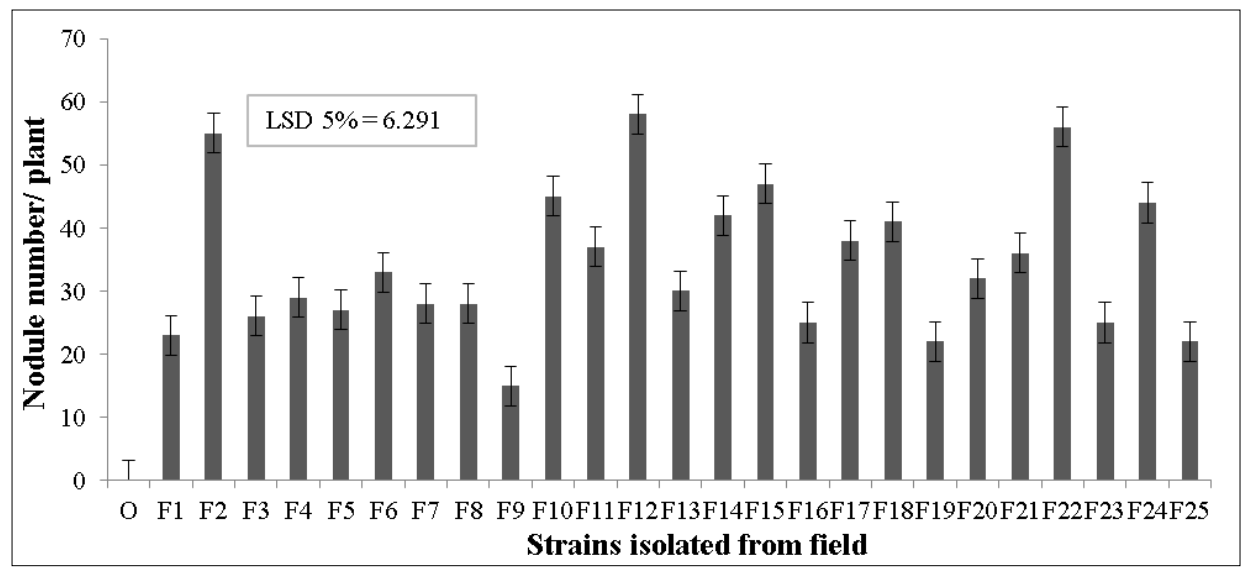

Fig. 3

Nodule number of soybean plants in a pot trial inoculated with Bradyrhizobium strains isolated from the field experiment (Legend: F1-F25: field isolates)

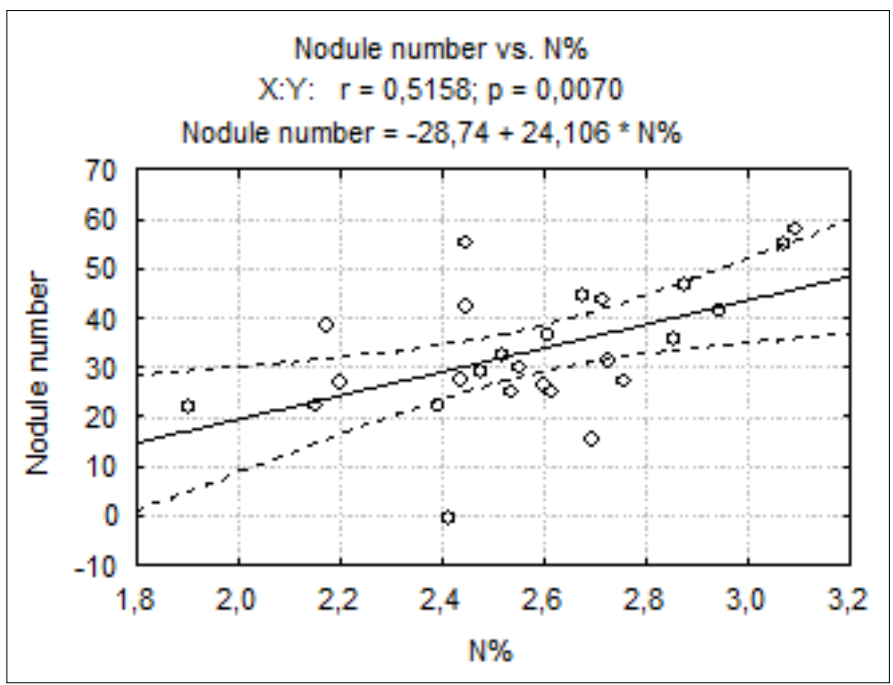

Fig. 4

Correlation between nodule number and $\mathrm{N} \%$ of soybean plants in the pot experiment

The average $\mathrm{P}$ content of non-inoculated plants was $1980 \mathrm{mg} \cdot \mathrm{kg}^{-1}$, while that of inoculated plants ranged from $1890 \mathrm{mg} \mathrm{kg}$ to $3170 \mathrm{mg} \cdot \mathrm{kg}^{-1}$, their average being $125 \%$ of the control. A significant correlation was found between plant $\mathrm{N} \%$ and $\mathrm{P}$ content (Fig. 5). 


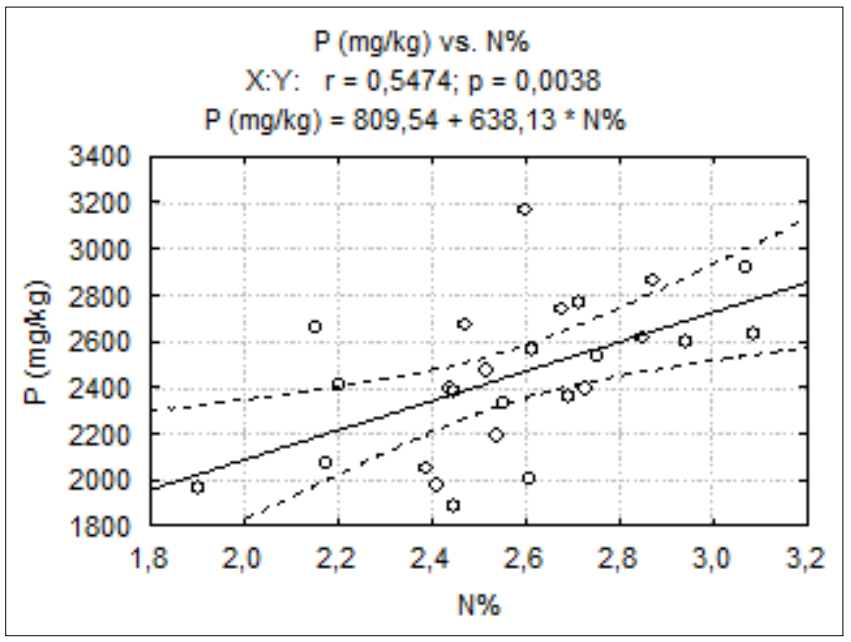

Fig. 5

Correlation between $\mathrm{N} \%$ and $\mathrm{P}$ content of soybean plants in the pot experiment

\section{Discussion}

\section{Soybean characteristics at full bloom}

The soil nitrogen contents recorded in the experimental field did not inhibit the efficiency of the inoculum, so differences in biomass production could be attributed to the efficiency of inoculation.

The height and dry weight of soybean were significantly higher in the inoculated field, confirming the efficiency of seed inoculation.

\section{Efficiency of soybean inoculation}

Bradyrhizobium strains were reported to be successful under neutral or slightly acidic pH conditions (ALBAREDA et al., 2009). This was confirmed in the present work, where the Bradyrhizobium strains in the inoculum effectively nodulated the given soybean species in neutral soil, though the individual strains exhibited different efficiency. This could be relevant in practical terms, because the efficiency of inoculation can be increased if host-specific microsymbionts are used. A similar conclusion was drawn from other work on beans (SHISANYA, 2002; CREWS et al., 2004) and soybean (KARR \& EMERICH, 1988). Therefore, the cost of inoculum production could be lowered while achieving enhanced inoculation efficiency. It was concluded that soybean required a homologous inoculant if the full benefit of bio$\operatorname{logical} \mathrm{N}_{2}$ fixation was to be seen. 
The average soybean yield in Hungary is $2.32 \mathrm{t} \cdot \mathrm{ha}^{-1}$ (HUNGARIAN CENTRAL STATISTICAL OFFICE, 2014), while in southern Europe it may be as high as $5 \mathrm{t} \cdot \mathrm{ha}^{-1}$ (AlBAREDA et al., 2009).

In the present experiment the soybean yield rose from 1.22 to $2.46 \mathrm{t} \cdot \mathrm{ha}^{-1}$ in response to inoculation, i.e. BNF led to a surplus yield of $1.24 \mathrm{t} \cdot \mathrm{ha}^{-1}$. On average as grain yield of $12.7 \mathrm{~kg}$ needs $1 \mathrm{~kg}$ of fixed nitrogen (SALVAGIOTTI et al., 2008), so the $1.24 \mathrm{t} \cdot \mathrm{ha}^{-1}$ surplus yield obtained in this experiment represented $98 \mathrm{~kg} \cdot \mathrm{ha}^{-1}$ fixed nitrogen.

It was earlier demonstrated that the addition of $\mathrm{N}$ fertiliser $\left(40-50 \mathrm{~kg} \mathrm{~N} \cdot \mathrm{ha}^{-1}\right)$ to inoculated soybean plants did not increase seed yields in comparison with treatments that were only inoculated (SZEGI et al., 1990; ALBAREDA et al., 2009). The soybean yield was more likely to respond to $\mathrm{N}$ fertilisation in high-yield (> 4.5 $\mathrm{t} \cdot \mathrm{ha}^{-1}$ ) environments (SALVAGIOTTI et al., 2008). Under the given climatic and soil ecological conditions the amount of fixed $\mathrm{N}$ was sufficient to cover the $\mathrm{N}$ demands of the regional average soybean yield without mineral $\mathrm{N}$ fertilisation.

\section{Testing of symbiotic efficiency in a pot experiment}

The total $\mathrm{N}$ content, dry weight, height and $\mathrm{N}$ production of soybean were higher in inoculated plants. The increases were closely correlated to the total nodule number, indicating the efficiency of BNF.

Giving legumes an adequate phosphorus supply has been proved to be crucial for obtaining high nitrogen fixation rates and growth. This is due to the high $\mathrm{P}$ requirement of energy transfer processes in the nodule. Increased P supplies from the soil resulted in increased $\mathrm{N}$ concentration and growth of several leguminous plants, including soybean (Glycine $\max$ (L.) Merr.) in experiments conducted by ROTARUA \& SINCLAIR (2008), who reported that plant nitrogen accumulation was linearly correlated with the $\mathrm{P}$ and $\mathrm{Fe}$ concentration of the nodules. As a consequence, the total nitrogen fixation rate was also correlated with the $\mathrm{P}$ and Fe concentrations of the nodules. However, a higher linear correlation was obtained for Fe concentration than for $\mathrm{P}$ concentration. The present pot experiment also proved that the $\mathrm{P}$ content of soybean was positively correlated with the nitrogen content.

The same positive correlation was found when more complex nutrition was used by applying compost products to alfalfa (KÖDÖBÖCZ et al., 2007) though no correlation with the $\mathrm{Fe}$ concentration was found. It should be noted that in the present study the $\mathrm{P}$ and $\mathrm{Fe}$ contents were only measured in aboveground biomass, not in the nodules.

\section{Summary}

The aim of this research was to study the inoculation efficiency of soybean (Glycine $\max (\mathrm{L}$.) Kurca) without mineral soil fertilisation on a loamic gleyic chernozem soil. The field experiment, carried out in the south of Hungary (Mezöhe- 
gyes), consisted of three treatments: (1) control, (2) inoculated with Bradyrhizobium inoculant and (3) inoculated with Bradyrhizobium plus foliar fertiliser.

The efficiency of inoculation was studied at full bloom. No nodule formation was observed without inoculation, while after seed inoculation six to seven composite, active nodules were developed. The $2.46 \mathrm{t} \cdot \mathrm{ha}^{-1}$ soybean yield recorded on the inoculated field was significantly higher than the $1.22 \mathrm{t} \cdot \mathrm{ha}^{-1}$ yield on the control field.

A total of 25 bacterial strains were isolated from the root nodules of soybean grown in the field experiment. Their symbiotic efficiency was verified in a pot experiment. All the isolated strains formed active nodules on soybean plants under laboratory conditions. A correlation was found the between nodule number and the nitrogen content of the aboveground biomass. Biological nitrogen fixation proportionally increased with the phosphorus and boron concentrations of the plants.

Keywords: soybean inoculation, symbiotic efficiency, Bradyrhizobium, biological nitrogen fixation

This research was funded by the Research Institute of Organic Agriculture (ÖMKI). The technical assistance of Mariann Mózes is highly appreciated.

\section{References}

Albareda, M., Rodríguez-Navarro, D. N. \& Temprano, F. J., 2009. Soybean inoculation: Dose, $\mathrm{N}$ fertilizer supplementation and rhizobia persistence in soil. Field Crops Research. 113. 352-356.

Biró, B., KöVes-PÉchy, K., SzILI-KovÁcs, T. \& SzEgI, J., 1993. Effect of fertilizer on spontaneous Rhizobium infection in Hungarian soils. In: Soil Resilience and Sustainable Land Use (Ed.: SzABOLCS, I.). Agrokémia és Talajtan. 42. 207-211.

BuZÁs, I. (ed.), 1993. Manual of Soil and Agrochemical Analysis 1 (In Hungarian). INDA 4231. Budapest.

CAliskan, S., OzKaya, I., CAliskan, M. E. \& Arslan, M., 2008.The effect of nitrogen and iron fertilisation on growth, yield and fertilizer use efficiency of soybean in a Mediterranean-type soil. Field Crop Research. 108. 126-132. FAO, 2012. Biofuel co-products as livestock feed - Opportunities and challenges. (Ed: HARINDER P. S.) Makkar. Rome.

Hungarian CENTRAL STATISTICAL OFFICE, 2014. http://www.ksh.hu/agricultural_census_long_time_series)

Hungria, M., FRANCHINI, J., CAMPO, R. \& GRAHAM, P., 2005. The importance of nitrogen fixation to soybean cropping in South America. In: Nitrogen Fixation in Agriculture, Forestry, Ecology, and the Environment. (Eds.: WERNER, D., \& NEWTON, W.) 25-42. Springer. Netherlands.

KARR, D. B. \& EMERICH, D. W., 1988. Uniformity of microsymbiont population from soybean nodules with respect to buoyant density. Plant Physiology. 86. 693-699.

Kim, O. S., ChO, Y. J., LeE, K., YoOn, S. H., KIM, M., NA, H., PARK, S. C., JeON, Y. S., LEE, J. H., YI, H., WON, S. \& CHUN, J., 2012. Introducing EzTaxon-e: a prokaryotic 
16S rRNA Gene sequence database with phylotypes that represent uncultured species. International Journal of Systematic and Evolutionary Microbiology. 62. 716721.

KöDÖBÖCZ, L., Biró, B., BAYOumi, H. E. A. F. \& KeCsKés, M., 2007. Activation of native Rhizobium population with composted and digested wastes on two alfalfa varieties. Cereal Research Communications. 35. 657-661.

KÖDÖBÖCZ, L., ZsírOS, L. R. \& MURÁNYI, A., 2011. Effect of soybean inoculation on chernozem soil (In Hungarian). Agrokémia és Talajtan. 60. (1) 233-244.

Matics, H., KASSAI, K., MÁtÉ, A. \& Biró, B., 2014. Rhizobium strain response of different origine to increasing fertilizer amendments. Növénytermelés. Suppl. 63. 323-326.

Rotarua, V. \& SinClair, T. R., 2008. Interactive influence of phosphorus and iron on nitrogen fixation by soybean. Environmental and Experimental Botany. 66. 94-99.

Salvagiotti, F., Cassman, K. G., Specht, J. E., Walters, D. T., Weiss, A. \& DoBERMANN, A., 2008. Nitrogen uptake, fixation and response to fertilizer $\mathrm{N}$ in soybeans: A review. Field Crops Research. 108. 1-13.

SHISANYA, C. A., 2002. Improvement of drought adapted tepary bean (Phaseolus acutifolius A. Gray var. latifolius) yield through BNF in semi-arid SE-Kenya. European Journal of Agronomy. 16. 13-24.

SZEGI, J., 1967. Importance of nitrogen-fixing microorganisms for soil fertility (In Hungarian). Agrokémia és Talajtan. 16. (1-4) 477-486.

SzeGI, J., GulYÁs, F., KÖVES-PÉCHY, K. \& SoÓS, T., 1990. Hungarian experiment with the utilization of rhizobial inoculant in practice. Agrokémia és Talajtan. 39. (3-4) 325-328.

VAN BERKUM, P. \& EARDLY, B. D., 1998. Molecular evolutionary systematics of the Rhizobiaceae. In: The Rhizobiaceae. (Eds.: SpAINK, H., Kondorosi, A. \& HoOyKaAS, P.) 1-24. Kluwer Academic Publishers. Dordrecht.

Versalovic, J., Schneider, M., De Bruijn, F. J. \& Lupski, J. R., 1994. Genomic fingerprinting of bacteria using repetitive sequence-based polymerase chain reaction. Methods in Molecular and Cellular Biology. 5. 25-40.

Vincent J. M., 1970. A Manual for the Practical Study of the Root Nodule Bacteria. Blackwell. Oxford.

WORLD REFERENCE BASE FOR SOIL RESOURCES, 2014. International soil classification system for naming soils and creating legends for soil maps. WORLD SOIL RESOURCES REPORTS 106. FAO, Rome. 181. 